Experimental evidence for a cost of resistance to the fungal pathogen, Batrachochytrium dendrobatidis, for the palmate newt, Lissotriton helveticus

Cheatsazan et al. 


\title{
Experimental evidence for a cost of resistance to the fungal pathogen, Batrachochytrium dendrobatidis, for the palmate newt, Lissotriton helveticus
}

Hamed Cheatsazan ${ }^{1 *}$, Ana P Lugon Gavinho de Almedia ${ }^{2}$, Andrew F Russell ${ }^{1,3}$ and Camille Bonneaud ${ }^{1,3}$

\begin{abstract}
Background: Batrachochytrium dendrobatidis $(B d)$, the causative agent of chytridiomycosis, is decimating amphibians worldwide. Unsurprisingly, the majority of studies have therefore concentrated on documenting morbidity and mortality of susceptible species and projecting population consequences as a consequence of this emerging infectious disease. Currently, there is a paucity of studies investigating the sub-lethal costs of $B d$ in apparently asymptomatic species, particularly in controlled experimental conditions. Here we report the consequences of a single dose of B. dendrobatidis zoospores on captive adult palmate newts (Lissotriton helveticus) for morphological and behavioural traits that associate with reproductive success.
\end{abstract}

Results: A single exposure to 2000 zoospores induced a subclinical Bd infection. One week after inoculation 84\% of newts tested positive for $B d$, and of those, $98 \%$ had apparently lost the infection by the day 30 . However, exposed newts suffered significant mass loss compared with control newts, and those experimental newts removing higher levels of $B d$ lost most mass. We found no evidence to suggest that three secondary sexual characteristics (areas of dorsal crest and rear foot webbing, and length of tail filament) were reduced between experimental versus control newts; in fact, rear foot webbing was 26\% more expansive at the end of the experiment in exposed newts. Finally, compared with unexposed controls, exposure to $B d$ was associated with a $50 \%$ earlier initiation of the non-reproductive terrestrial phase.

Conclusions: Our results suggest that $B d$ has measureable, but sub-lethal effects, on adult palmate newts, at least under the laboratory conditions presented. We conclude that the effects reported are most likely to be mediated through the initiation of costly immune responses and/or tissue repair mechanisms. Although we found no evidence of hastened secondary sexual trait regression, through reducing individual body condition and potentially, breeding season duration, we predict that $B d$ exposure might have negative impacts on populations of palmate newts through reducing individual reproductive success and adult recruitment.

Keywords: Body condition, Cost of immunity, Chytridiomycosis, Emerging infectious disease, Resistance, Secondary sexual traits

\footnotetext{
* Correspondence: h.cheatsazan@gmail.com

${ }^{1}$ Station d'Ecologie Expérimentale, USR 2936, 2 Route du CNRS, 09200

Moulis, France

Full list of author information is available at the end of the article
} 


\section{Background}

Batrachochytrium dendrobatidis $(B d)$, the causative agent of chytridiomycosis, has been implicated in worldwide amphibian declines [1]. Although $B d$ is able to infect a wide range of species and hence displays extreme host generality [2-4], amphibian morbidity and mortality in response to infection is highly variable and host-species specific $[5,6]$. For example, while some studies report devastating consequences of $B d$ infection [7-9], others have shown different levels of resistance to $B d$ infection (capacity to prevent or clear $B d$ infection) and have provided experimental evidence showing some species are able to clear $B d$ infection [7,10-13]. In several species, infiltration of neutrophils, lymphocytes, macrophages and inflammation have been reported on the skin of susceptible (i.e., those which are not able to clear $B d$ infection or to prevent colonization of $B d)$ amphibians [11,14-16]. Histological examinations of resistant hosts have revealed that $B d$ infections can cause skin injuries similar to those observed in susceptible species, albeit distributed more patchily on the skin [10-12]. These results suggest that those amphibians that are apparently resistance to $B d$ infection might still experience sublethal costs but whether any such costs are likely to impair traits associated with reproductive success and survival is unclear.

It is well known that pathogens exert significant cost for the host $[17,18]$. Costs may be manifest through the host's energetic and cellular response to the infection [19-21], through the pathogens acquisition of host resources, or through inducing greater host susceptibility to other pathogens [22-24]. As such, hosts might show clinical symptoms and visible damage [24], but even where such effects are lacking, significant negative consequences can arise through reductions in investment in traits associated with fitness (e.g., growth, survival and reproduction, $[18,19])$. As a consequence, in species exhibiting apparent resistance to $B d$, we might also expect there to be sub-lethal costs of infection and for such costs to influence populations. In support, a number of studies in frogs and toads have reported subclinical effects of $B d$ on tadpole growth [25-28], as well as adult body size [29] and body condition [30]. Nevertheless, in such cases, tests of the consequences of $B d$ infection for traits important in reproduction (morphology, behaviour) of resistant amphibians are generally lacking.

The palmate newt, Lissotriton helveticus (Cuadata: Salamandridae; formerly Triturus helveticus), is a common, semi-aquatic amphibian of Western Europe. Palmate newts inhabit aquatic habitats with still or very slowmoving water during the breeding season, but otherwise have a terrestrial life style [31], occupying moist habitats and refugia [32]. Males develop large ornaments when they enter water for breeding, manifested as a low, straight edged crest which extends dorsally, a thread-like filament projecting from the end of the tail and conspicuous webbing between the toes of the hind feet [33]. These secondary sexual characteristics have been shown to be associated with male reproductive success [31,34-36]. They then gradually start to regress as the newts leave their aquatic habitat, but may not necessarily have fully disappeared as individuals start their migration to their terrestrial feeding [33].

Interestingly, palmate newts have been reported in several $B d$ infected sites across Europe and have been found to test positively for $B d$ (global Bd maps, see [37] for details). Despite this, no morbidity or mass mortality have been reported $[37,38]$ and under laboratory conditions, excessive weekly exposures to more than $10^{6} \mathrm{Bd}$ zoospores per week for more than 4 weeks does not induce symptomatic chytridiomycosis even up to 40 days following a month-long exposure course (Cheatsazan, unpublished results 2011, $\mathrm{n}=35$ newts). These observations suggest that this species exhibits some level of resistance to $B d$. However, the consequences of exposure to $B d$, which will most likely occur during the aquatic phase as a result of increased probability of exposure to waterborne $B d$ zoospores, have not been investigated for this species. Here, we inoculated a group of wild-caught palmate newts experimentally with a single dose of $B d$ (18 controls and 50 exposed) and monitored $B d$ infection, survival and clinical symptoms, as well as changes in morphological and behavioural traits known to be associated with reproductive success in this species. Our specific aim was to use this experiment to test: (1) whether palmate newts become infected by exposure to low doses of $B d$, whether they show external symptoms and whether they are able to tolerate or clear the infection; (2) the consequences of $B d$ exposure and infection load for secondary sexual characters in males; (3) the consequences of $B d$ exposure and infection load for mass change in both males and females; and (4) whether exposure to $B d$ is associated with changes in the probability of an early entry into the terrestrial phase. Throughout, we consider sex differences, where possible.

\section{Methods}

In mid May 2011, 68 newts (34 males and 34 females) in aquatic phase were captured in narrow streams on the borders of Bouconne forest, Haute Garonne, France $\left(43^{\circ}\right.$ $39^{\prime} \mathrm{N}$ and $1^{\circ} 14^{\prime} \mathrm{W}, 190 \mathrm{~m}$ altitude). Our rationale for using wild-caught rather than laboratory-derived newts was that we wished to use individuals as close as possible to their natural state. The sites used are in a forest reserve with natural and man-made streams, and are located about $100 \mathrm{~km}$ outside the current extent of the known $B d$ infection zone. In addition, our inspections for $B d$ in this area since 2009 have failed to detect evidence of $B d$ infection of any amphibian species in the 
area, and all animals brought back to the laboratory tested negative for $B d$. Male and female newts were randomly paired and transferred into plastic tanks (205× $205 \times$ $140 \mathrm{~mm}$ ). Our reason for this is that wished to examine the effects of $B d$ exposure on male secondary sexual characteristics, which we considered to be likely influenced by the presence of a female. Each tank contained 1.0 litre of aged tap water and a hollow brick for shelter. We randomly assigned tanks to one of 2 treatment groups: controls (9 males, 9 females) and $B d$-exposed ( 25 males and 25 females). All newts were maintained in the laboratory for 7 days prior to experimentation and were provided with live midge larvae (blood worms), daphnia and/or tubifex every two days. Food was provided by 'sucking' a known quantity of liquid (tube length $\mathrm{x}$ diameter = $55 \mathrm{cmm} \times 0.5 \mathrm{~cm}$ ) containing roughly 75 larvae. Although the precise number of larvae was unknown, there is no reason to suppose this varied systematically between experimentally exposed and control tanks. Room temperature was maintained at $18.6 \pm 1.9^{\circ} \mathrm{C}$ throughout the experiment. Light exposure was adjusted weekly to equal the average day length of the first and of the last days of the focal week (approximately $14 \mathrm{~h}$ light: $10 \mathrm{~h}$ dark). Water was changed 3 days after inoculation and then weekly thereafter to prevent bacterial blooms in the tank. This also means that levels of $B d$ loads detected were unlikely to be explained by zoospore survival in the water [39].

$B d$ cultures were prepared from a $B d$ extract of an infected tadpole from an introduced population of American bullfrog (Lithobates catesbeianus) in southern France (for extraction protocol see [40]). This extract was grown in $1.0 \%$ Trypton (SCHARLAU, cat. No 07-119) and $0.32 \mathrm{~g} \mathrm{l}^{-1}$ glucose (ROTH, cat. No X997) in ultrapure water. Cultures were incubated at $18.5^{\circ} \mathrm{C}$ to optimize growth of the fungus [5]. Approximately one hour prior to inoculation, we counted approximately 160 active zoospores $\times \mathrm{ml}^{-1}$ of the 5th passage of our culture using a haemocytometer. We then added $12 \mathrm{ml}$ of this culture to each $B d$ exposed tank ( 2000 zoospores $\times l^{-1} \times \operatorname{tank}^{-1}$ ). The experiment was stopped 30 days post-inoculation, when about approximately half of the newts had entered or were entering the terrestrial phase of the season $(\mathrm{t}$ phase). When a newt consistently remained out of the water for five consecutive days, we considered the day the newt had left the water for the first time as the start of $t$ phase. Animal capture was with permission of the prefecture of Haute Garonne (Permission No. 2009-12). Animal housing facility and experiments comply with the regulations of the housing organization (CNRS: National centre for scientific research) and the current rules of France.

Infection was detected by quantitative amplification of $B d$-DNA content of weekly swab samples (from: forelimbs, hind limbs, abdomen and cloaca) using fine tip dry swabs (Tubed sterile dryswabTM tip, Medical wire
\& Equipment, cat. No MW100). Swab samples were taken at upon arrival, day 7, 14, 21, and 30 after the first inoculation from all individuals. Quantitative PCR's were conducted as described in [41], and after incorporating the changes suggested by Kriger et al. and Hyatt et al. [42-44] except that the we reduced the final volume of reactions to $10 \mu \mathrm{l}$ due to higher sensitivity of our q-PCR machine (Mastercycler ep realplex4, Eppendorf). Throughout this paper, results of all quantifications are presented in $B d$ Genome Equivalent ( $B d \mathrm{GE}$ ) per swab bout. In addition to standard duplicates and negative controls, we also included 6-12 samples of control newts in each test plates of exposed samples and utilized internal positive control reagent in all samples (TaqMan Exogenous Internal Positive Control). To ensure the efficiency of inoculations, we also analysed swab samples of 66 individuals of the same population, after 2 weekly exposures to $10^{6}$ zoospores of the same $B d$ strain. The average $B d$ load of these newts, one week after the second inoculation, was (mean \pm S.E.) $442.2 \pm 187.4 B d \mathrm{GE}$, showing the $B d$ strain and inoculation method was able to generate an infection in this population.

On days 0 and 30 post-inoculation, we measured body mass using a digital scale $( \pm 0.01$ gram $)$. Snout-to-vent length (SVL) and male secondary sexual traits were measured by ImageJ software on digital photographs of all individuals: area of tail crest, length of tail filament, and average of webbed area of hind feet (left and right feet) one day before inoculation and day 30 after inoculation, according to [36]. Photographs were taken on a single plastic board with a millimetre scaled area of $2 \times 10 \mathrm{~cm}$. All morphological measurements were taken twice by the same person $(\mathrm{HC})$ and their average was used in statistical analyses. In all cases a strong correlation $(r \geq 0.90, p<$ $0.001)$ was observed between replicates. Finally, we recorded survival, and the start of t-phase as well as symptoms of clinical chytridiomycosis [5].

\section{Infection patterns and symptoms}

Changes in the probability of being infected during the experiment were analysed by fitting whether (1) or not (0) a newt was infected on a given day as the response term in generalized linear mixed-effects model (GLMM) with a binomial error structure and logit link function. The binomial denominator and dispersion parameters were 1. Changes to infection loads during the course of the experiment, were analysed using a GLMM with Poisson error structure and log-link function in which load size (numbers of $B d \mathrm{GE}$ ) was fitted as the response term. In both models, individual subjects' codes (ID's) nested within box number were fitted as random terms to account for repeated sampling of each. The SVL and body mass of individuals on day zero were fitted as covariates, while sex, days after the first inoculations $(7,14,21,30)$ and their 
interaction were fitted as fixed effects. Finally, throughout the experiment we examined the animals for signs to $B d$ mediated symptoms.

\section{Secondary sexual characteristics in males}

Analysis of change in male secondary sexual characters over the course of the experiment was conducting using multivariate analysis of variance, in order to account for multiple correlated terms of interest (crest area, tail filament length and rear foot webbing: Spearman's rank correlations between the traits, $\mathrm{r}_{\mathrm{s}}=0.4-0.86, \mathrm{p}<0.005$ $0.0001)$. The changes in each trait were fitted as the response terms, while proportional mass change was fitted as a covariate to account for changes in body condition, and treatment was fitted as a the fixed effect of interest. Because in this case we only used a single measure from a single individual from each box (i.e. the male), there was no need to conduct a mixed model in this analysis.

\section{Mass loss in males and females}

The effect of $B d$ on mass was investigated in two ways. First, an analysis of the effect of treatment on mass change was conducted by fitting mass change between day 0 and 30 as the response term in a general linear model with normal errors. Body length and mass at experimental onset were fitted as covariates, while sex and treatment were fitted as the primary fixed effects of interest, along with their interaction. Second, an analysis of the effect of $B d$-load change during the course of the experiment on mass change was conducted in the same way, but wherein treatment was swapped for load change among exposed individuals. Because both of these analyses included a male and a female from the same box, it could be argued that such pairings are not independent units. However, initial residual maximum likelihood models fitting box number as a random term showed that the box from which individuals were obtained had a negative component of variance, indicating that the variation within boxes was indistinguishable from that between boxes. We therefore elected for the more parsimonious GLM rather than REML approach, since the results were almost identical and the former allows estimation of variance explained.

\section{Terrestrial phase}

The probability that individuals initiated $\mathrm{t}$-phase within the 30-day experimental period was investigated by fitting whether (1) or not (0) individuals entered t-phase as the response term using two GLMs with binomial error structures with logit link functions. In the first case, treatment was fitted as the primary factor of interest, and in the second, treatment was replaced by $B d$-load. In each case, body length (SVL) and mass at experimental onset were fitted as covariates, and sex was fitted as an additional factor. In both analyses, we investigated the effect of tank identity in GLMMs, but in both cases it represented a negative component of variance.

All statistics were conducted in Genstat Release 14 (Rothamsted Experimental Station, Harpenden, UK). The statistics are provided for all terms included in the models, and effect sizes \pm standard errors are provided for terms of interest. Terms were dropped from models when their exclusion failed to generate a significant loss of model variance. All $\mathrm{p}$ values provided are two-tailed.

\section{Results}

\section{Infection patterns and symptoms}

At experimental onset, all newts tested negative for $B d$, but following exposure to $B d, 94 \%$ of individuals became infected. Of these, most became infected in the first week, although $4 \%$ became infected by the end of week two and $2 \%$ were found to be infected at the end of week three. Only $4 \%$ of newts remained infected 30 days after the onset of the experiment. As a consequence, the probability that individuals were infected with $B d$ changed substantially during the course of the month-long experiment (Figure 1a). Larger newts were less likely to be infected on a given day (effect \pm S.E. $=-0.20 \pm 0.097 ; \chi^{2}=4.16, \mathrm{df}=1$, $\mathrm{p}=0.041$ ), but there was no effect of initial body mass (effect \pm S.E. $\left.=-0.73 \pm 1.46 X^{2}=0.49, \mathrm{df}=1, \mathrm{p}=0.49\right)$ and no differences between the sexes $\left(x^{2}=0.15, d f=1, p=0.70\right.$; Figure 1a) on patterns of infection.

Over the course of the experiment, $B d$ loads ranged from 0-14 BdGE per swab. Newts that were long (SVL) had reduced loads on average (GLMM with Poisson errors, effect \pm S.E.; $-0.075 \pm 0.035 ; x^{2}=4.70, d f=1, p=$ 0.030 ), but there was no effect of body mass at the onset of the experiment $\left(0.42 \pm 0.44 ; x^{2}=0.90, d f=1, p=0.34\right)$ and no difference between the sexes $\left(x^{2}=0.01, \mathrm{df}=1\right.$, $\mathrm{p}=0.93$, Figure $1 \mathrm{~b}$ ). As with the incidence data above, $B d$ loads varied dramatically throughout the month-long experiment: in both sexes, $B d$ loads were at their maximum seven days after inoculation and declined to zero after a month (Figure 1b).

The results above suggest that palmate newts are resistant to $B d$. In support, we found no evidence to suggest that $B d$ induces mortality or visible clinical symptoms in the captive palmate newts. During the course of our 30day study, only three newts died. Two infected newts died ( 1 male and 1 female) 15 days post-inoculation, and one control (a female) did so 24 days following the onset of the experiment. Prior to their death, none of the exposed newts showed symptoms of clinical chytridiomycosis, such as skin lesions, haemorrhage, or absence of righting reflex $[45,46]$. $B d$ contents of swab samples taken the day before of death of the two treated newts were 0 and $14 B d G E$ in female and male individual, respectively. 


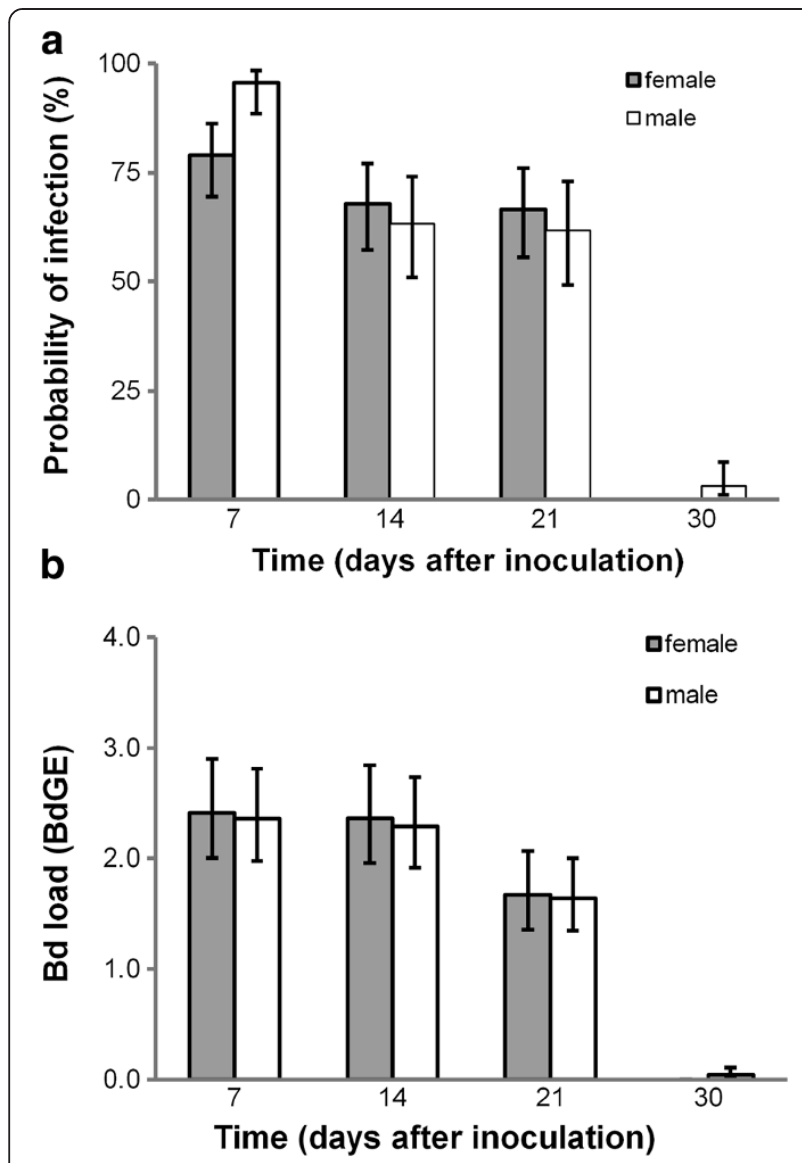

Figure 1 Changes in probability and intensity of the infection during the course of the experiment. (a) The probability of infection gradually decreased after the first week and by 30 days post-inoculation, most newts tested negative for $B d$ (GLMM: days post-inoculation; $x^{2}=30.12, d f=3, p<0.0001$; interaction sex $x$ days post-inoculation $x^{2}=2.68, d f=3, p=0.44$ ). (b) The average infection burden was constant until 2 weeks after inoculation; during the third week after inoculation the infection intensity started to decline and generally reached zero at day 30 post-inoculation (GLMM: days post-inoculation; $x^{2}=9.20, d f=3, p<0.001$; interaction sex $x$ days post-inoculation $x^{2}=0.01, d f=3, p=0.99$ ). Figures show predicted means $\pm S E$ generated from the mixed model analyses. In both analyses, tank had no influence on patterns of $B d$ infection (tank component $=0$ ), but there was some consistency in the prevalence of $B d$ infection within versus among individuals (component $=0.01 \pm 0.009$ (S.E.)) and a significant difference between individuals in $B d$ loads (component $=0.12 \pm 0.004$ (S.E.)).

\section{Secondary sexual characteristics in males}

Male palmate newts show three obvious morphological characteristics during the aquatic breeding phase. At experimental onset, the mean $( \pm S D)$ crest area, tail filament length and hind food webbing area were 110.4 $( \pm 12.2) \mathrm{mm}^{2}, 4.6( \pm 1.2) \mathrm{mm}, 18.2( \pm 1.3) \mathrm{mm}^{2}$, respectively. The onset of the experiment was timed to coincide with the peak breeding season and hence the maximum extent of male secondary sexual characteristic sizes. During the course of the experiment, crest and hind food web area declined by $37 \%$ and $31 \%$, respectively, while tail filament was reduced in length by $68 \%$ (Figure 2). A multivariate analysis of variance (MANOVA) revealed that after controlling for the proportion of mass lost $\left(\mathrm{F}_{3,26}=3.04\right.$, $\mathrm{p}=0.047$ ), there was an overall effect of treatment on the reduction of the extent of secondary sexual characteristics $\left(\mathrm{F}_{3,26}=5.43, \mathrm{p}=0.005\right)$. However, univariate ANOVAs showed that this overall effect was driven entirely by the effect of Bd treatment on a reduction (not increase) of the loss of hind food web area (crest area, $\mathrm{F}_{1,28}=0.45, \mathrm{p}=$ 0.51 ; filament length, $\mathrm{F}_{1,28}=0.01, \mathrm{p}=0.94$; hind food web area, $\mathrm{F}_{1,28}=12.37, \mathrm{p}=0.002$ ).

\section{Mass loss in males and females}

At the time of capture, females were slightly longer than males (mean \pm SD snout-vent length (hereafter body length) $=34.9 \pm 1.9$ vs. $32.6 \pm 1.8 \mathrm{~mm}$ : $\mathrm{t}$-test, $\mathrm{t}_{66}=5.10$, $\mathrm{p}<0.001$ ), but there was no difference in their respective masses $\left(1.19 \pm 0.23\right.$ vs. $\left.1.20 \pm 0.20 \mathrm{~g}: \mathrm{t}_{63}=0.49, \mathrm{p}=0.63\right)$. Individuals that were heavy at experimental onset lost significantly more mass over the 30-day experiment than those that were light (GLM: $\mathrm{F}_{1,63}=30.72, \mathrm{p}<0.001$ ), but there was no effect of body length (GLM: effect \pm s.e. $\left.=-0.0064 \pm 0.0058 ; F_{1,62}=1.22, p=0.27\right)$. After controlling for significant effects of the former, we found that exposed newts lost 33\% more mass than control newts, with treatment explaining $7.5 \%$ of the variation in mass change during the experiment $\left(\mathrm{F}_{1,63}=10.55, \mathrm{p}=0.002\right.$; Figure 3a). Males and females lost similar amounts of mass $\left(\mathrm{F}_{1,62}=1.23, \mathrm{p}=0.27\right)$ and the effect of experimental treatment on mass loss did not differ between the sexes $\left(\mathrm{F}_{1,61}=0.28, \mathrm{p}=0.60\right.$; Figure $\left.3 \mathrm{a}\right)$.

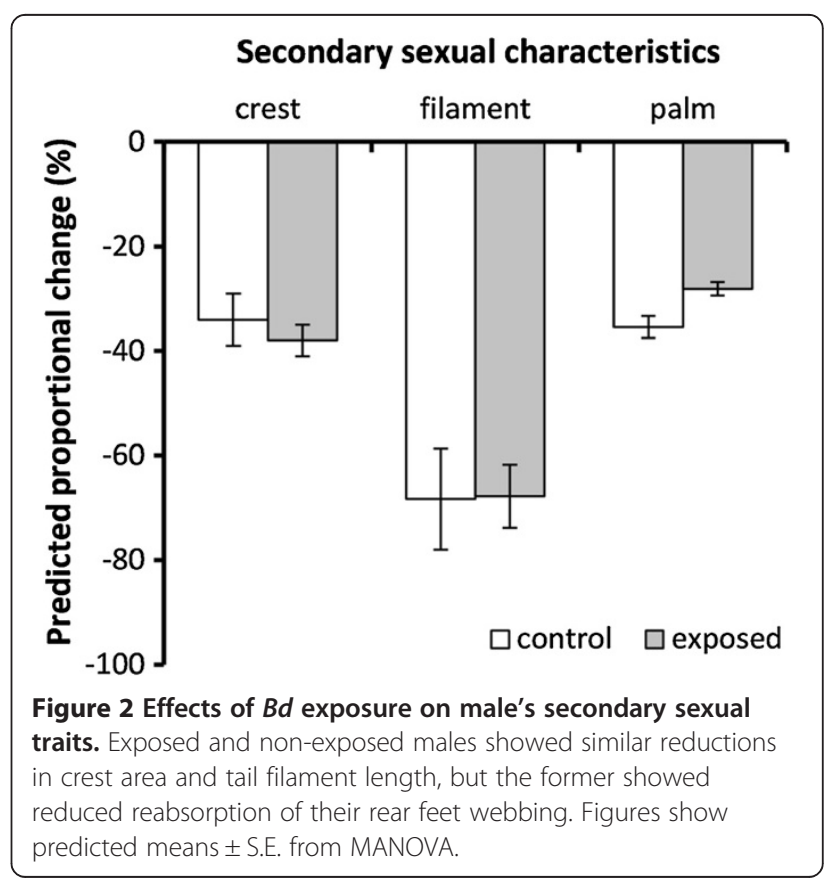




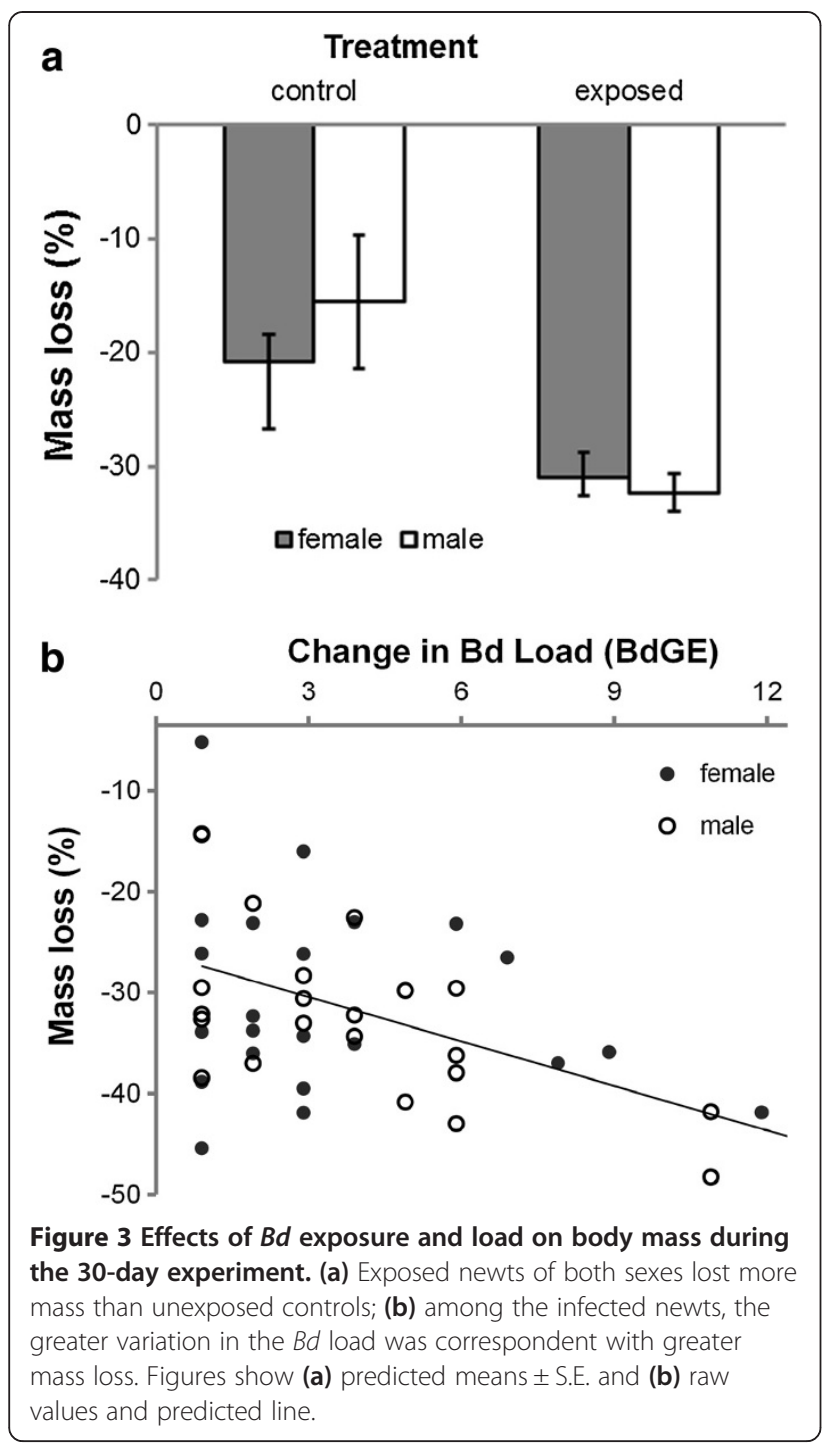

The results above suggest that palmate newts suffer a cost of clearing $B d$ from their system. However, a better test of this hypothesis is to investigate the relationship between the change in $B d$ load and the change in mass over the course of the experiment. The mass lost by experimental newts increased as a function of increasing body mass at the onset of the experiment (GLM: effect \pm S.E. $=0.27 \pm 0.066 ; \mathrm{F}_{1,44}=17.61, \mathrm{p}<0.001$ ), but was uninfluenced by SVL (effect \pm S.E. $=-0.0022 \pm$ $0.0062 ; F_{1,43}=0.13, p=0.73$ ). After controlling for the effects of mass at experimental onset, we found a significant negative relationship with $B d$ load change and mass loss, with newts losing $5 \%$ of their body mass for every four $B d$ GE's that they cleared (effect \pm S.E. $=0.051 \pm$ 0.012; $\mathrm{F}_{1,44}=18.36, \mathrm{p}<0.001, \mathrm{R}^{2}=20 \%$; Figure $3 \mathrm{~b}$ ). This effect was common to both males and females (GLM: sex" $B d$ change interaction; $\mathrm{F}_{1,42}=0.03, \mathrm{p}=0.86$ ).
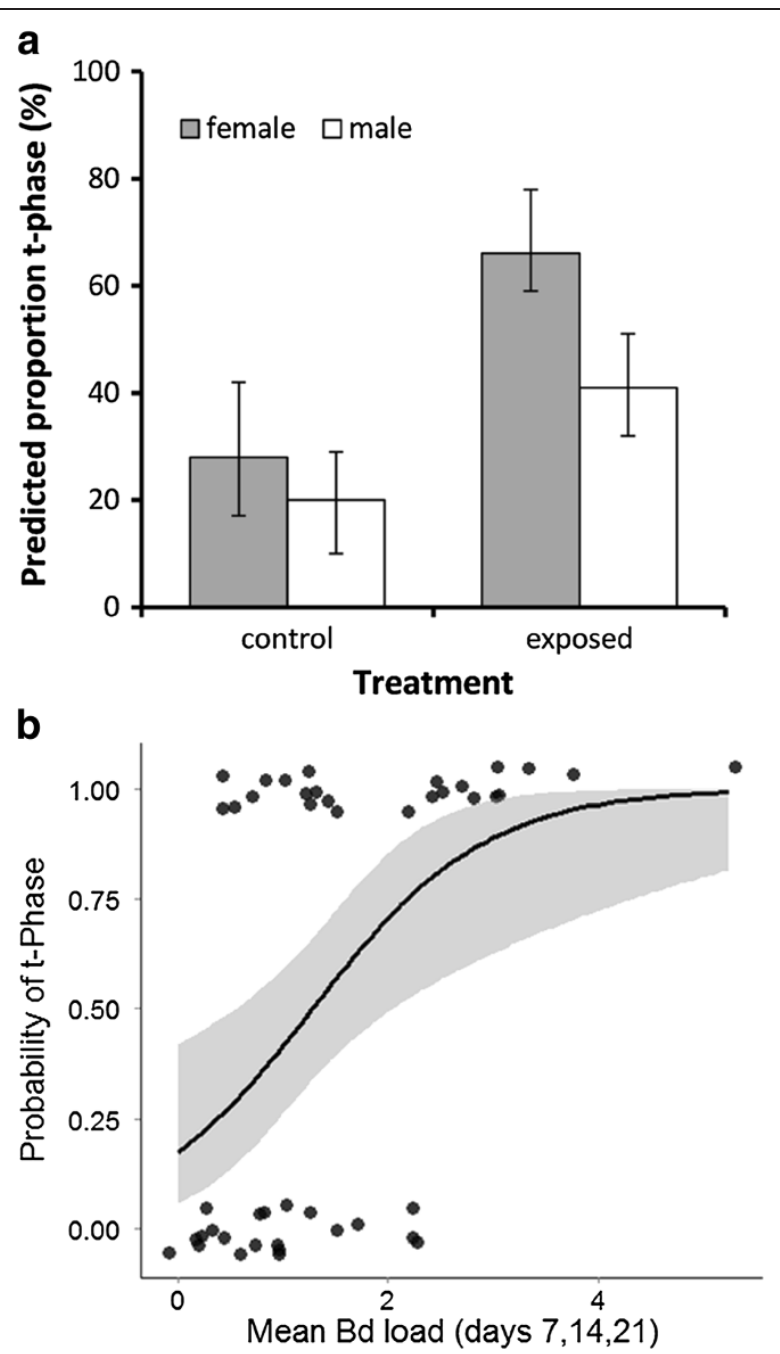

Figure 4 Consequences of $B d$-exposure and $B d$-infection for probability of termination of aquatic breeding season.

(a) Exposed individuals were more likely to enter the terrestrial phase than unexposed controls; and (b) higher infection intensities were associated with increased probability of transition to terrestrial phase. Figures show GLM predicted (a) predicted percentages from $\mathrm{a} G L M \pm S E$ and (b) shows the relationship between average $B d$ load and occurrence of t-phase among the $B d$ exposed newts. The line represents the linear predictor of the GLM (probability of t-phase) and the shaded area shows \pm SE of the predictor.

\section{Terrestrial phase}

Overall, $46 \%$ of newts were judged to have entered t-phase by the end of the 30-day experiment. There were nonsignificant tendencies for males to enter $\mathrm{t}$-phase after females (GLM, $X^{2}=1.31, \mathrm{p}=0.25$ ) and those in poor body condition to enter $\mathrm{t}$-phase before those in good condition (body mass correcting for body length, $x^{2}=2.56, p=0.11$ ). After controlling for these effects, we found that exposed newts were $50 \%$ more likely to enter into t-phase during the 30-day experiment that control newts $\left(x^{2}=3.99, p=\right.$ 0.046; Figure 4a). 
Within the exposed individuals, males and females had a similar probability of entering into t-phase (GLM; Sex, $X^{2}=1.02, p=0.31$ ). There was no effect of body length on the probability of entering $t$ phase (SVL effect \pm S.E. $=$ $0.027 \pm 0.15 ; x^{2}=0.03, p=0.86$ ), but those individuals in poor conditions were more likely to enter the $t$-phase than those in better condition (initial mass effect \pm S.E. $-3.46 \pm$ 1.69; $\left.x^{2}=4.71, p=0.030\right)$. After controlling for these effects, we found that newts were more likely to enter $t$ phase if they had high average $B d$ loads during the first three weeks of the experiment, independently of sex $(B d$ load effects \pm S.E. $=0.73 \pm 0.33 ; \chi^{2}=5.92, p=0.015 ;$ sex $x$ $B d$ load $\chi^{2}=0.01, \mathrm{p}=0.99$; Figure $4 \mathrm{~b}$ ).

\section{Discussion}

Our results suggest that the $B d$ dose administered is capable of inducing a subclinical infection in the palmate newt within one to two weeks after inoculation. We found no evidence to suggest that $B d$ caused signs of chytridiomycosis [46] or death, and indeed, virtually all exposed newts appeared to have cleared any infection by one month postinoculation. These results complement circumstantial field evidence documenting that in $B d$ areas, palmate newts appear not to suffer mass mortality (e.g., $[37,38])$. Nevertheless, our evidence also suggest that such apparent resistance to $B d$ comes at a cost of increased mass loss during the aquatic phase and a more rapid transition to terrestrial t-phase compared to non-exposed controls. Within exposed newts, both the amount of mass lost and probability of entering $\mathrm{t}$-phase increased as a function of increasing pathogen load clearance. By contrast, the rate of loss of secondary sexual characteristics were generally not influenced by $B d$ infection, with the exception of hind foot webbing that remained longer in exposed newts than controls. While the devastating impacts of $B d$ on amphibians are well publicised [7-9,47], much less is known about the extent, form and underlying causes of more subtle symptoms in apparently resistant amphibian species. Our results suggest that caution should be exercised before concluding that $B d$ has negligible consequences for apparently resistant species.

$B d$ is known to invade the host epidermis; feeding on various nutrients (e.g., keratin), causing pathological abnormalities and impairing critical cutaneous functions, such as the maintenance of osmotic balance (reviewed in [5]). Although $B d$ infection can have devastating consequences (see Introduction), accumulating evidence suggests that some amphibians only exhibit subclinical symptoms and might be able to effectively clear the infection through mechanisms such as antimicrobial peptides [13,48], $B d$ killing microbial flora on their skin [49-51], anti- $B d$ immunoglobulin's [52-54], increasing body temperature during the infection [55] and improvements to dietary condition [56] (reviewed in [57]). In such circumstances, individuals might still suffer costs: (i) because pathogens impair body functioning; (ii) because mounting an immune response or repairing damaged tissues requires energy; (iii) because pathogens actually consume host energy resources; and/or (iv) because immune-associated illness-induced anorexia reduces energy intake [23,58-60]. For instance, in wild frog populations, $B d$ infection has found to be associated with smaller body size $[29,61]$, although the mechanism(s) causing the reduction in body size in these frog studies was unclear. The evidence for our study suggests that increased mass loss might be mediated by a cost of immunity [22], but verification of this as a specific mechanism needs elucidating through more targeted experimentation in our and other studies. For example, we are not able to rule out a role of adaptive anorexia, but we suggest that such an effect is unlikely to explain our results fully, since newts were not fed adlib and we noticed no obvious surplus of food in experimental tanks. Indeed, that a recent study has shown experimentally that mounting an innate immune response (skin peptides) against $B d$ comes at cost to host body condition [62], provides some tentative support for our conclusions.

We found little evidence to suggest that the regression of secondary sexual characteristics were hastened by exposure to $B d$, but we found some support for the possibility that breeding season duration might be curtailed. Both the regression of sexually selected characteristics and transition into t-phase are thought to be largely under hormonal control [63-65]. Although, we were not able to measure neuroendocrine changes of the exposed and infected newts, our results fit well with the current knowledge of amphibians' stress responses and its impacts on reproduction. In amphibians, exposure to pathogens can cause a rapid release of anti-microbial peptides [66,67] through activation of hypothalamic-pituitary-adrenal (HPA) axis (=stress axis in mammals) [67-69]. Stimulation of this axis can result in inhibition of production and release of stress hormone (i.e. corticosterone) [70,71] which, in urodeles, inhibits the courtship behaviour, development/maintenance of male secondary sexual traits and triggers the migration toward the terrestrial habitat [63,64,72-74]. At the behavioural level, a decrease of prolactin triggers the termination of aquatic phase and migration toward terrestrial habitat while at a morphological level the decrease of prolactin induces the decline of tail crest $[63,64,73,74]$. However, the decline of hind feet webbing is mediated by a different mechanism which involves a synergetic effect of several hormones $[73,75]$. Therefore, the slowed reduction of hind feet webbings, in comparison to tail crest and tail filament, might be due to the difference of the hormonal bases which control these traits. In order to elucidate the potential mechanisms of slowed regression of foot webbing (in comparison with other secondary sexual traits, or vice versa) as well as early entry into t-phase, more studies are required. In addition, 
in order to understand the potential consequences, the exact role and relative importance of each sexually selected trait in female choice is required, as is the consequences of the size of each trait for survival on transition to the t-phase.

Although, for obvious ethical and conservation reasons, we were unable to measure the consequences of experimental infection for individual fitness in the wild, we suggest the consequences of $B d$ that we observed are likely to be significant $[26,29,30,76]$. In palmate newts, mating success is likely to be influenced by the duration of their aquatic phase, and is known to be conditiondependent: female fecundity and male display rate are both highly demanding energetically [77-79]. It is also highly probable that the success of terrestrial migrations are at least partly associated with having sufficient energy reserves as is the ability to survive winter hibernation, since the annual rate of survival of newts is fairly low (i.e. $\leq 50 \%$, see $[80,81]$ ) and newts consume almost all their resources during the winter [78]. Our ability to project the population consequences of sub-lethal infections requires an understanding of whether or not individuals can acquire adaptive immunity to $B d$ or whether individuals with primed immune system remain susceptible to $B d$. Where the former is the case, we would expect $B d$ to have little impact on palmate newt's populations once resistance spreads in the populations (e.g. see [62,82]). On the other hand, if the latter is true, the sub-lethal consequences observed in this study are likely to have more significant population consequences, with possible impairment of female fecundity, juvenile recruitment and adult survival. Currently, it is unclear whether amphibian species that suffer subclinical effects of $B d$ are declining, as one might expect from our results. We urge that future studies are careful to monitor population sizes of all amphibian species in a given area, and attempt to determine whether $B d$ can also have population consequences, even for apparently resistant species. Further, in the advent of such declines being apparent, it is important to determine whether such declines are generated through biased effects on each sex or age class.

\section{Conclusion}

The costs of pathogen infection are common and include a range of sub-lethal symptoms including reduced growth, increased mass loss, increased metabolic rate and/or a readjustment of life history strategies $[22,83,84]$. Our results suggest that subclinical costs of $B d$ infection can exert significant costs on an apparently resistant host amphibian, with potential threatening consequences on long term population viability. Indeed, $B d$ infected palmate newts suffered from a decrease in body condition relative to controls and had delayed absorption of one temporary adaptations for aquatic life; both of which might impede the success of terrestrial migration. In addition, they showed earlier initiation of $\mathrm{t}$-phase, which might reduce the duration of a breeding season, and hence the number of offspring produced by a given population. Furthermore, in addition to the general inhibitory effects of stress on amphibian reproduction, chronic exposure to $B d$ zoospores in the aquatic habitat may trigger a chronic activation of the stress (HPA) axis which might increase an individual's susceptibility to other pathogens as well as other environmental stressors. Further studies are required in this species and other apparently asymptomatic species, in order to further appreciate the extent, form and mechanism of sub-lethal costs of $B d$ infection in amphibian species.

\section{Competing interests}

The authors confirm that this work is not a subject of financial and nonfinancial competing interests.

\section{Authors' contributions}

$\mathrm{HC}$ conceived and conducted the experiments with help from AP. The analyses were performed and the paper was written by HC, AFR and CB. All authors read and approved the final manuscript.

\section{Acknowledgements}

We are grateful to Jean Clobert and Michel Baguette for logistical support and helpful comments, Jeremie Cornuau for his assistance in the field and Michele Huet for her help in molecular analyses. We thank the following for funding: Marie Curie grant (CB; FP7-PEOPLE-IRG-2008, \#239257). AP conducted this work in part fulfilment of a Master's Degree at the University of Dijon.

\section{Author details}

${ }^{1}$ Station d'Ecologie Expérimentale, USR 2936, 2 Route du CNRS, 09200 Moulis, France. ${ }^{2}$ Organism and Population Biology, University of Burgundy, 21000 Dijon, France. ${ }^{3}$ Centre for Ecology \& Conservation, College of Life and Environmental Sciences, University of Exeter Cornwall Campus, Penryn TR10 9EZ, Cornwall, UK.

Received: 24 December 2012 Accepted: 20 June 2013

Published: 19 July 2013

\section{References}

1. Kilpatrick AM, Briggs CJ, Daszak P: The ecology and impact of chytridiomycosis: an emerging disease of amphibians. Trends Ecol Evol 2010, 25(2):109-118.

2. Bonaccorso E, Guayasamin JM, Mendez D, Speare R: Chytridiomycosis as a possible cause of population declines in Atelopus cruciger (Anura: Bufonidae). Herp Rev 2003, 34:331-334.

3. Green DE, Sherman CK: Diagnostic histological findings in Yosemite toads (Bufo canorus) from a die-off in the. J Herpetol 1970, 2001:92-103.

4. Kriger KM, Hero JM, Ashton KJ: Cost efficiency in the detection of chytridiomycosis using PCR assay. Dis Aquat Organ 2006, 71(2):149-154.

5. Voyles J, Rosenblum EB, Berger L: Interactions between Batrachochytrium dendrobatidis and its amphibian hosts: a review of pathogenesis and immunity. Microb Infect 2011, 13(2):25-32.

6. Gervasi S, Gondhalekar C, Olson D, Blaustein A: Host Identity Matters in the Amphibian-Batrachochytrium dendrobatidis System: Fine-Scale Patterns of Variation in Responses to a Multi-Host Pathogen. PLoS One 2013, 8(1):e54490.

7. Retallick RWR, McCallum H, Speare R: Endemic infection of the amphibian chytrid fungus in a frog community post-decline. PLOS Biol 2004, 2(11):e351.

8. Schloegel LM, Hero JM, Berger L, Speare R, McDonald K, Daszak P: The decline of the sharp-snouted day frog (Taudactylus acutirostris): the first documented case of extinction by infection in a free-ranging wildlife species? Ecohealth 2006, 3(1):35-40. 
9. Skerratt LF, Berger L, Speare R, Cashins S, McDonald KR, Phillott AD, Hines $H B$, Kenyon N: Spread of chytridiomycosis has caused the rapid global decline and extinction of frogs. Ecohealth 2007, 4(2):125-134.

10. Daszak P, Strieby A, Cunningham AA, Longcore JE, Brown CC, Porter D: Experimental evidence that the bullfrog (Rana catesbeiana) is a potential carrier of chytridiomycosis, an emerging fungal disease of amphibians. Herp J 2004, 14:201-208.

11. Davidson EW, Parris M, Collins JP, Longcore JE, Pessier AP, Brunner J: Pathogenicity and transmission of chytridiomycosis in tiger salamanders (Ambystoma tigrinum). Copeia 2003, 2003(3):601-607.

12. Reeder NMM, Pessier AP, Vredenburg VT: A Reservoir Species for the Emerging Amphibian Pathogen Batrachochytrium dendrobatidis Thrives in a Landscape Decimated by Disease. PLoS One 2012, 7(3):e33567.

13. Rollins-Smith $L A$ : The role of amphibian antimicrobial peptides in protection of amphibians from pathogens linked to global amphibian declines. Biochim Biophys Acta Biomembranes 2009, 1788(8):1593-1599.

14. Berger L, Hyatt AD, Speare R, Longcore JE: Life cycle stages of the amphibian chytrid Batrachochytrium dendrobatidis. Dis Aquat Organ 2005, 68(1):51-63.

15. Nichols DK, Lamirande EW, Pessier AP, Longcore JE: Experimental transmission of cutaneous chytridiomycosis in dendrobatid frogs. J Wildl Dis 2001, 37(1):1-11.

16. Pessier AP, Nichols DK, Longcore JE, Fuller MS: Cutaneous chytridiomycosis in poison dart frogs (Dendrobates spp.) and White's tree frogs (Litoria caerulea). J Vet Diagn Invest 1999, 11(2):194-199.

17. Lochmiller RL, Deerenberg C: Trade-offs in evolutionary immunology: just what is the cost of immunity? Oikos 2000, 88(1):87-98.

18. Sheldon BC, Verhulst S: Ecological immunology: costly parasite defences and trade-offs in evolutionary ecology. Trends Ecol Evol 1996, 11(8):317-321.

19. Bonneaud C, Mazuc J, Gonzalez G, Haussy C, Chastel O, Faivre B, Sorci G: Assessing the cost of mounting an immune response. Am Nat 2003 161(3):367-379.

20. Moret $Y$, Schmid-Hempel P: Survival for immunity: the price of immune system activation for bumblebee workers. Science 2000 290(5494):1166-1168.

21. Råberg L, Nilsson JÅ, Ilmonen P, Stjernman M, Hasselquist D: The cost of an immune response: vaccination reduces parental effort. Ecol Lett 2000, 3(5):382-386.

22. Bonneaud C, Balenger SL, Hill GE, Russell AF: Experimental evidence for distinct costs of pathogenesis and immunity against a natural pathogen in a wild bird. Mol Ecol 2012, 21(19):4787-4796.

23. Hornef MW, Wick MJ, Rhen M, Normark S: Bacterial strategies for overcoming host innate and adaptive immune responses. Nat Immunol 2002, 3(11):1033-1040.

24. Casadevall A, Pirofski L: The damage-response framework of microbial pathogenesis. Nat Rev Microbiol 2003, 1(1):17-24.

25. Davidson C, Benard MF, Shaffer HB, Parker JM, O'Leary C, Conlon JM, RollinsSmith LA: Effects of chytrid and carbaryl exposure on survival, growth and skin peptide defenses in foothill yellow-legged frogs. Environ Sci Technol 2007, 41(5):1771-1776.

26. Garner TWJ, Walker SF, Bosch J, Leech S, Marcus Rowcliffe J, Cunningham AA, Fisher MC: Life history tradeoffs influence mortality associated with the amphibian pathogen Batrachochytrium dendrobatidis. Oikos 2009, 118(5):783-791.

27. Venesky MD, Parris MJ, Altig R: Pathogenecity of Batrachochytrium dendrobatidis in larval Ambystomatid Salamanders. Herp Cons Biol 2010 5(2):174-182.

28. Venesky MD, Parris MJ, Storfer A: Impacts of Batrachochytrium dendrobatidis infection on tadpole foraging performance. Ecohealth 2009, 6(4):565-575

29. Burrowes PA, Longo AV, Rodríguez CA: Potential fitness cost of Batrachochytrium dendrobatidis in eleutherodactylus coqui, and comments on environment-related risk of infection. Herpetotropicos 2007, 4(2):51-57.

30. Richards-Zawacki C: Thermoregulatory behaviour affects prevalence of chytrid fungal infection in a wild population of Panamanian golden frogs. Proc R Soc Lond, Ser B: Biol Sci 2010, 277(1681):519-528.

31. Secondi J, Hinot E, Djalout Z, Sourice S, Jadas-Hécart A: Realistic nitrate concentration alters the expression of sexual traits and olfactory male attractiveness in newts. Funct Ecol 2009, 23(4):800-808.
32. Nöllert A, Nöllert C: Guide des amphibiens d'Europe. Paris: Delachaux et Niestlé; 2003.

33. Griffiths RA, Mylotte VJ: Observations on the development of the secondary sexual characters of male newts. Triturus vulgaris and T. helveticus. J Herpetol 1988, 22(4):476-480.

34. Baker JMR: Body condition and tail height in great crested newts, Triturus cristatus. Anim Behav 1992, 43:157-159.

35. Green AJ: Large male crests, an honest indicator of condition, are preferred by female smooth newts, Triturus vulgaris(Salamandridae) at the spermatophore transfer stage. Anim Behav 1991, 41(2):367-369.

36. Cornuau JH, Rat M, Schmeller DS, Loyau A: Multiple signals in the palmate newt: ornaments help when courting. Behav Ecol Sociobiol 2012, 66:1045-1055.

37. Olson DH, Aanensen DM, Ronnenberg KL, Powell Cl, Walker SF, Bielby J, Garner TWJ, Weaver G, Fisher MC, The Bd Mapping G: Mapping the Global Emergence of Batrachochytrium dendrobatidis, the Amphibian Chytrid Fungus. PLOS ONE 2013, 8(2):e56802.

38. Wood LR, Griffiths RA, Schley L: Amphibian chytridiomycosis in Luxembourg. Bull Soc Nat Luxemb 2009, 110:109-114.

39. Johnson ML, Speare R: Survival of Batrachochytrium dendrobatidis in water: quarantine and disease control implications. Emerging Infect Dis 2003, 9(8):922.

40. Longcore JE: Recognizing, isolating, and culturing Batrachochytrium dendrobatidis from amphibians. In Proceedings of "Getting the Jump! on Amphibian Diseases Conference/Workshop. Queensland, Australia: James Cook University; 2000:52-54. August.

41. Boyle DG, Boyle DB, Olsen V, Morgan JA, Hyatt AD: Rapid quantitative detection of chytridiomycosis (Batrachochytrium dendrobatidis) in amphibian samples using real-time Taqman PCR assay. Dis Aquat Organ 2004, 60(2):141-148.

42. Bielby J, Bovero S, Sotgiu G, Tessa G, Favelli M, Angelini C, Doglio S, Clare F, Gazzaniga E, Lapietra F, et al: Fatal chytridiomycosis in the tyrrhenian painted frog. Ecohealth 2009, 6(1):27-32.

43. Walker SF, Salas MB, Jenkins D, Garner TW, Cunningham AA, Hyatt AD, Bosch J, Fisher MC: Environmental detection of Batrachochytrium dendrobatidis in a temperate climate. Dis Aquat Organ 2007, 77(2):105-112.

44. Kriger KM, Hines HB, Hyatt AD, Boyle DG, Hero JM: Techniques for detecting chytridiomycosis in wild frogs: comparing histology with realtime Taqman PCR. Dis Aquat Organ 2006, 71(2):141-148.

45. Berger L, Longcore JE, Speare R, Hyatt AD, Skerratt LF: Amphibian Biology, Volume 8. Australia: Surrey Beatty \& Sons; 2009.

46. Voyles J, Young S, Berger L, Campbell C, Voyles WF, Dinudom A, Cook D, Webb R, Alford RA, Skerratt LF, et al: Pathogenesis of chytridiomycosis, a cause of catastrophic amphibian declines. Science 2009, 326(5952):582-585.

47. Fisher MC, Garner TW, Walker SF: Global emergence of Batrachochytrium dendrobatidis and amphibian chytridiomycosis in space, time, and host. Annu Rev Microbiol 2009, 63:291-310.

48. Rollins-Smith LA, Conlon JM: Antimicrobial peptide defenses against chytridiomycosis, an emerging infectious disease of amphibian populations. Dev Comp Immunol 2005, 29(7):589-598.

49. Harris RN, Brucker RM, Walke JB, Becker MH, Schwantes CR, Flaherty DC, Lam BA, Woodhams DC, Briggs CJ, Vredenburg VT, et al: Skin microbes on frogs prevent morbidity and mortality caused by a lethal skin fungus. ISME J 2009, 3(7):818-824.

50. Harris RN, Lauer A, Simon MA, Banning $J$, Alford RA: Addition of antifungal skin bacteria to salamanders ameliorates the effects of chytridiomycosis. Dis Aquat Organ 2009, 83(1):11-16.

51. Lam BA, Walke JB, Vredenburg VT, Harris RN: Proportion of individuals with antiBatrachochytrium dendrobatidis skin bacteria is associated with population persistence in the frog Rana muscosa. Biol Conserv 2010, 143(2):529-531.

52. Ramsey JP, Reinert LK, Harper LK, Woodhams DC, Rollins-Smith LA: Immune defenses against Batrachochytrium dendrobatidis, a fungus linked to global amphibian declines, in the South African clawed frog. Xenopus laevis. Infect Immun 2010, 78(9):3981.

53. Rollins-Smith LA, Ramsey J, Pask J, Reinert L, Woodhams D: Amphibian immune defenses against chytridiomycosis: impacts of changing environments. Integr Comp Biol 2011, 51(4):552-562.

54. Rollins-Smith LA, Ramsey JP, Reinert LK, Woodhams DC, Livo LJ, Carey C: Immune defenses of Xenopus laevis against Batrachochytrium dendrobatidis. Front Biosci (Schol Ed) 2009, 1:68-91.

55. Rowley J, Alford R: Hot bodies protect amphibians against chytrid infection in nature. Sci Rep 2013, 3:1515. 
56. Venesky MD, Wilcoxen TE, Rensel MA, Rollins-Smith L, Kerby JL, Parris MJ: Dietary protein restriction impairs growth, immunity, and disease resistance in southern leopard frog tadpoles. Oecologia 2012, 169(1):23-31.

57. Woodhams DC, Bosch J, Briggs CJ, Cashins S, Davis LR, Lauer A, Muths E, Puschendorf R, Schmidt BR, Sheafor B: Mitigating amphibian disease: strategies to maintain wild populations and control chytridiomycosis. Frontiers in Zoology 2011, 8(1):8.

58. Little TJ, Killick SC: Evidence for a cost of immunity when the crustacean Daphnia magna is exposed to the bacterial pathogen Pasteuria ramosa. J Anim Ecol 2007, 76(6):1202-1207.

59. Martin LB, Scheuerlein A, Wikelski M: Immune activity elevates energy expenditure of house sparrows: a link between direct and indirect costs? Proc R Soc Lond Ser B: Biol Sci 2003, 270(1511):153-158.

60. Murray MJ, Murray AB: Anorexia of infection as a mechanism of host defense. Am J Clin Nutrit 1979, 32(3):593-596.

61. Kriger K, Pereoglou F, Hero J-M: Latitudinal variation in the prevalence and intensity of chytrid (Batrachochytrium dendrobatidis) infection in eastern Australia. Conservation biology: the journal of the Society for Conservation Biology 2007, 21(5):1280-1290.

62. Woodhams D, Bigler L, Marschang R: Tolerance of fungal infection in European water frogs exposed to Batrachochytrium dendrobatidis after experimental reduction of innate immune defenses. BMC Vet Res 2012, 8:197.

63. Kikuyama S, Yazawa T, Abe S, Yamamoto K, Iwata T, Hoshi K, Hasunuma I, Mosconi G, Polzonetti-Magni A: Newt prolactin and its involvement in reproduction. Can J Physiol Pharm 2000, 78(12):984-993.

64. Mazzi V, Vellano C: Prolactin and reproduction. In Hormones and reproduction in fishes, amphibians, and reptiles. vol. 1st edition. Edited by Norris DO, Jones RE. New York and London: Plenum Press; 1987:87-115.

65. Tassava RA, KUENZLI C: The effects of Prolactin and Thyroxine on tailk fin height, habitat chioce, and forelimbe regeneration in the adult newt (Notophthalmus viridescens). Ohio J Sci 1979, 79(2):32-37.

66. Miele R, Ponti D, Boman H, Barra D, Simmaco M: Molecular cloning of a bombinin gene from Bombina orientalis: detection of NF-kappaB and NF-IL6 binding sites in its promoter. FEBS Lett 1998, 431(1):23-28.

67. Rollins-Smith L: Neuroendocrine-immune system interactions in amphibians: implications for understanding global amphibian declines. Immunol Res 2001, 23(2-3):273-280.

68. Kapcala L, Chautard T, Eskay R: The protective role of the hypothalamicpituitary-adrenal axis against lethality produced by immune, infectious, and inflammatory stress. Ann N Y Acad Sci 1995, 771:419-437.

69. Gabor C, Fisher M, Bosch J: A Non-Invasive Stress Assay Shows That Tadpole Populations Infected with Batrachochytrium dendrobatidis Have Elevated Corticosterone Levels. PLoS One 2013, 8(2):e56054.

70. Kloas W, Hanke W: Neurohypophysial hormones and steroidogenesis in the interrenals of Xenopus laevis. Gen Comp Endocrinol 1990, 80(2):321-330.

71. Malagón M, Ruiz-Navarro A, Torronteras R, Gracia-Navarro F: Effects of ovine CRF on amphibian pituitary ACTH and TSH cells in vivo: a quantitative ultrastructural study. Gen Comp Endocrinol 1991, 83(3):487-497.

72. Brown SC, Stocking Brown P, Yamamoto K, Matsuda K, Kikuyama S: Amphibian prolactins: Activity in the eft skin transepithelial potential bioassay. Gen Comp Endocrinol 1991, 82(1):1-7.

73. Singhas CA, Dent JN: Hormonal control of the tail fin and of the nuptial pads in the male red-spotted newt. Gen Comp Endocrinol 1975, 26(3):382-393

74. Toyoda F, Tanaka S, Matsuda K, Kikuyama S: Hormonal control of response to and secretion of sex attractants in Japanese newts. Physiol Behav 1994, 55(3):569-576

75. Sever DM, Staub NL: Hormones, Sex Accessory Structures, and Secondary Sexual Characteristics in Amphibians. In Hormones and Reproduction in Vertebrates Volume 2: Amphibians. Edited by In Norris DOe, vol. 2. Maryland Heights, Missouri: Elsevier Inc; 2010.

76. May S, Zeisset I, Beebee T, J. C: Larval fitness and immunogenetic diversity in chytrid-infected and uninfected natterjack toad (Bufo calamita) populations. Conserv Genet 2011, 12:805-811.

77. Harrison JD, Gittins SP, Slater FM: The breeding migration of Smooth and Palmate newts (Triturus vulgaris and T. helveticus) at a pond in mid Wales. J Zool 1983, 199(2):249-258.

78. Verrell PA, Halliday TR, Griffiths ML: The annual reproductive cycle of the smooth newt (Triturus vulgaris) in England. J Zool 1986, 210(1):101-119.

79. Wells KD: The ecology and behavior of amphibians. Chicago: University of Chicago Press; 2007.
80. Jehle R, Arntzen JW: Post-breeding migrations of newts (Triturus cristatus and T. marmoratus) with contrasting ecological requirements. J Zool 2000, 251(3):297-306.

81. Bell G: The life of the smooth newt (Triturus vulgaris) after metamorphosis. Ecol Monogr 1977, 47(3):279-299.

82. Bonneaud C, Balenger SL, Russell AF, Zhang J, Hill GE, Edwards SV: Rapid evolution of disease resistance is accompanied by functional changes in gene expression in a wild bird. Proc Natl Acad Sci USA 2011, 108(19):7866-7871.

83. Eraud C, Duriez $\mathrm{O}$, Chastel $\mathrm{O}$, Faivre B: The energetic cost of humoral immunity in the Collared Dove, Streptopelia decaocto: is the magnitude sufficient to force energy-based trade-offs? Funct Ecol 2005, 19(1):110-118.

84. Bosch J, Carrascal LM, Duran L, Walker S, Fisher MC: Climate change and outbreaks of amphibian chytridiomycosis in a montane area of Central Spain; is there a link? Proc Biol Sci 2007, 274(1607):253-260.

doi:10.1186/1472-6785-13-27

Cite this article as: Cheatsazan et al.: Experimental evidence for a cost of resistance to the fungal pathogen, Batrachochytrium dendrobatidis, for the palmate newt, Lissotriton helveticus. BMC Ecology 2013 13:27.

\section{Submit your next manuscript to BioMed Central and take full advantage of:}

- Convenient online submission

- Thorough peer review

- No space constraints or color figure charges

- Immediate publication on acceptance

- Inclusion in PubMed, CAS, Scopus and Google Scholar

- Research which is freely available for redistribution

Submit your manuscript at www.biomedcentral.com/submit
C) Biomed Central 